Research Article

\title{
Gamma-Tocotrienol Stimulates the Proliferation, Differentiation, and Mineralization in Osteoblastic MC3T3-E1 Cells
}

\author{
Weili Xu $\mathbb{D}^{1},{ }^{1}$ Pan He, ${ }^{1}$ Shenghua He $\mathbb{D}^{1},{ }^{1}$ Pengju Cui, ${ }^{1}$ Yaqing Mi, ${ }^{1}$ Yang Yang, \\ Yang $\mathrm{Li}^{2}{ }^{2}$ and Shaobo Zhou (iD) ${ }^{3}$ \\ ${ }^{1}$ Department of Food Science and Engineering, School of Chemistry and Chemical Engineering, Harbin Institute of Technology, \\ Harbin 150001, China \\ ${ }^{2}$ Department of Central Laboratory, The First Affiliated Hospital of Harbin Medical University, Harbin 150090, China \\ ${ }^{3}$ School of Life Science, Institute of Biomedical and Environmental Science and Technology, University of Bedfordshire, \\ Luton LU1 3JU, UK
}

Correspondence should be addressed to Weili Xu; weilixu1977@sina.com and Shaobo Zhou; shaobo.zhou@beds.ac.uk

Received 11 October 2017; Accepted 6 December 2017; Published 15 January 2018

Academic Editor: Ji Kang

Copyright (c) 2018 Weili Xu et al. This is an open access article distributed under the Creative Commons Attribution License, which permits unrestricted use, distribution, and reproduction in any medium, provided the original work is properly cited.

\begin{abstract}
Gamma-tocotrienol, a major component of tocotrienol-rich fraction of palm oil, has been suggested to exhibit bone protective effects in vivo. However, the effects of $\gamma$-tocotrienol on osteoblast cells are still unclear. In this study, the effects of $\gamma$-tocotrienol on the proliferation, differentiation, and mineralization in osteoblastic MC3T3-E1 cells were investigated. Our results showed that $\gamma$-tocotrienol $(2-8 \mu \mathrm{mol} / \mathrm{L})$ significantly improved the cell proliferation $(p<0.05)$, but it did not affect cell cycle progression. $\gamma$-Tocotrienol significantly increased alkaline phosphatase (ALP) activity $(p<0.05)$, secretion levels of osteocalcin (OC) and osteonectin (ON), and mRNA levels of collagen type I ( Col I) of MC3T3-E1 cells. Meanwhile, we found that $\gamma$-tocotrienol is promoted in differentiation MC3T3-E1 cells by upregulation of the expression of Runx2 protein. Moreover, the number of bone nodules increased over 2.5 -fold in cells treated with $\gamma$-tocotrienol $(2-8 \mu \mathrm{mol} / \mathrm{L})$ for $24 \mathrm{~d}$ compared to control group. These results indicated that $\gamma$-tocotrienol at low dose levels, especially $4 \mu \mathrm{mol} / \mathrm{L}$, could markedly enhance the osteoblastic function by increasing the proliferation, differentiation, and mineralization of osteoblastic MC3T3-E1 cells. Moreover, our data also indicated that Runx2 protein may be involved in these effects. Further studies are needed to determine the potential of $\gamma$-tocotrienol as an antiosteoporotic agent.
\end{abstract}

\section{Introduction}

Osteoporosis affects $1 / 3$ of women and $1 / 5$ of men over the age of 50 years worldwide; it affects $75 \%$ of aged population in Europe, USA, and Japan [1]; and in China alone, there are 0.21 billion of people with low bone density [2]. Osteoporosis is characterized by low bone density and deterioration of bone microarchitecture [3]. Osteoporosis causes progressive bone loss and arises from an imbalance of bone resorption and formation in the bone remodeling process. There are many factors which can cause osteoporosis such as menopause, aging, thyroid diseases, and calcium deficiency [4].

Currently, most drugs for the treatment of osteoporosis focus on improvement of bone resorption, via either reducing osteoclast number (such as bisphosphonates and estrogen) or inhibition of osteoclast activity (such as cathepsin $\mathrm{K}$ inhibitors). However, they have little ability to stimulate new bone synthesis $[1,5-7]$. Since new bone formation depends primarily on the function of osteoblasts, the agents acting by either increasing the proliferation or inducing differentiation of the osteoblasts could enhance bone formation $[8,9]$. Furthermore, the potential bone-forming agents or drugs currently available either may have serious side-effects or may not improve bone quality to reduce the susceptibility to fracture. Thus, the discovery of natural dietary compounds that promote bone formation may be able to avoid the occurrence of the adverse effects of traditional drug in humans and will be of great interest. 
<smiles>[R]c1c([R])c2c(c(O)c1C)OC(C)(CC/C=C(/C)CC/C=C(/C)CCC=C(C)C)CC2</smiles>

(a)

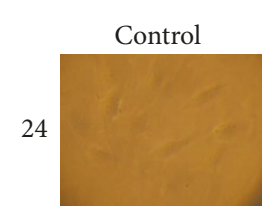

(h) 48
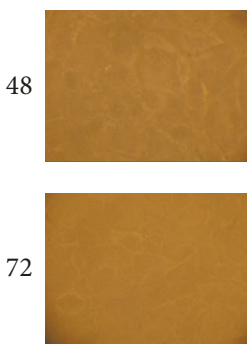

$(\mu \mathrm{mol} / \mathrm{L})$
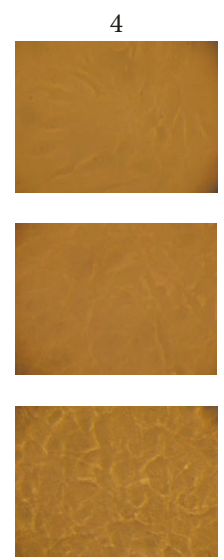

(c)

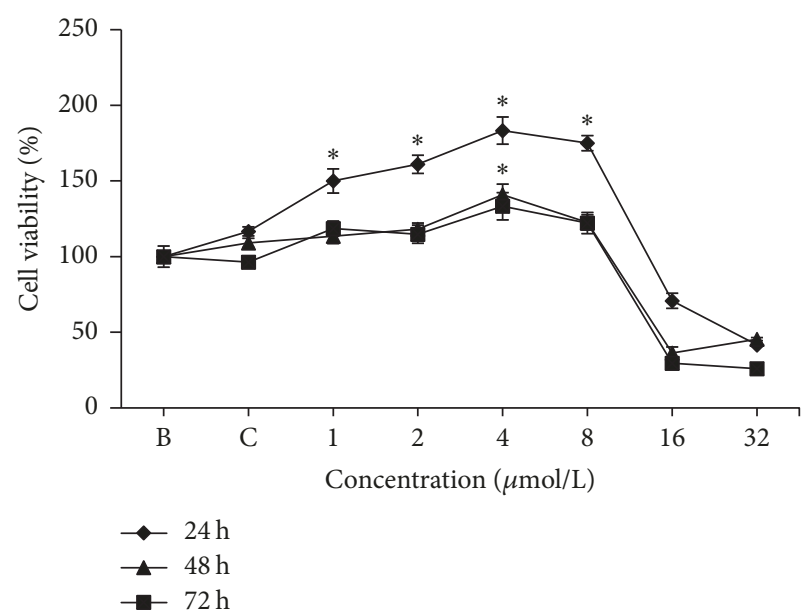

(b)

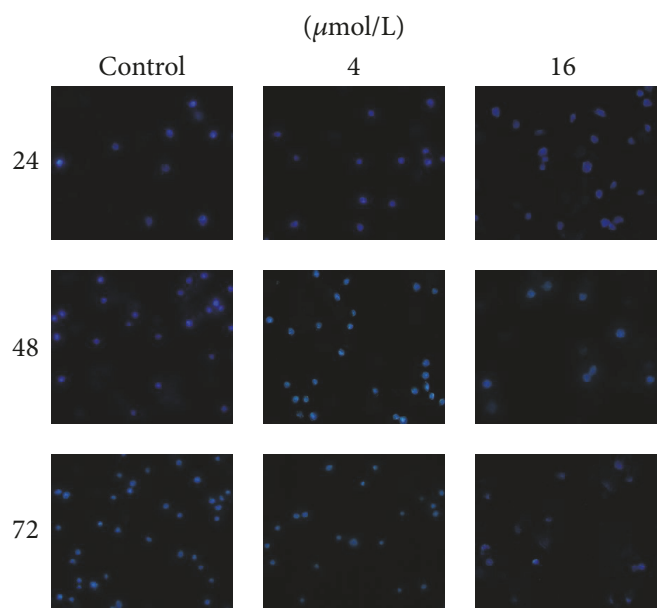

(d)

FIGURE 1: Effect of $\gamma$-tocotrienol on viability in MC3T3-E1 cells. (a) The structure of tocopherol and tocotrienol. (b) Cells were exposed to different doses of $\gamma$-tocotrienol for 24, 48, or $72 \mathrm{~h}$. Cell viability was determined by MTT assay. (c) Cells were treated with different doses of $\gamma$-tocotrienol for 24,48 , and $72 \mathrm{~h}$. Images were captured by phase contrast microscopy (200x). (d) Cells were stained with DAPI dye for measuring nuclear morphological alteration (DAPI, 200x). Data are expressed as mean $\pm \operatorname{SD}(n=3) .{ }^{*} p<0.05$, compared to the control group. B: blank control; C: ethanol control.

Tocotrienols and tocopherols, two subclasses of vitamin $\mathrm{E}$, are abundant in food ingredients such as palm oil, rice bran oil, barley, corn, oats, rye, and wheat $[10,11]$. Each of them has four stereoisomers, respectively, namely, $\alpha-, \beta-, \gamma^{-}$, and $\delta$-tocopherols or tocotrienols (Figure 1(a)). Tocopherols contain a saturated phytol side chain in the chroman ring. Tocotrienols differ from the tocopherols in that they contain three double bonds in the side chain [12]. In previous studies, tocotrienols have been shown to have better bone protective effects when compared to $\alpha$-tocopherol in animal osteoporosis models [13-19]. Furthermore, studies also showed that tocotrienols were able to prevent and even reverse osteoporosis in estrogen deficiency, testosterone deficiency, glucocorticoid excess, and nicotine exposure [15-17, 20-23]. Previous study demonstrated that palm tocotrienol is even more effective than calcium in preventing bone loss caused by estrogen deficiency [24]. Tocotrienols showed a better bone anabolic action than tocopherol in normal male rats $[14,25]$. The protective mechanism of tocotrienols on bone was thought to be contributed by its antioxidant property $[17,18,26]$.

Although in vivo studies have shown that tocotrienols exhibit bone protective activity, there is paucity of in vitro studies to determine the effect of tocotrienols on bone cells, especially tocotrienol isomers [15-17, 20-25, 27]. $\gamma$ Tocotrienol, the most abundant isomer in palm oil (up to $49 \%$ of the vitamin E) [28], was the most potent isomer of tocotrienols in promotion bone formation and protection in the in vivo studies [14, 29]. However, few studies had reported the direct evidence on the effect of $\gamma$-tocotrienol in osteoblast function. The purpose of the present study was to understand the effects of $\gamma$-tocotrienol on cell proliferation, differentiation, and mineralization in osteoblastic MC3T3-E1 cells. 
TABLE 1: Sequences of primers for real-time PCR.

\begin{tabular}{lllc}
\hline Gene & \multicolumn{1}{c}{ Forward primer $\left(5^{\prime}-3^{\prime}\right)$} & Reverse primer $\left(5^{\prime}-3^{\prime}\right)$ & Size $(\mathrm{bp})$ \\
\hline GAPDH & CCCAGAAGACTGTGGATGG & GGATGCAGGGATGATGTTCT & 81 \\
Ki-67 & GACAGCTTCCAAAGCTCACC & GTGTCCTTAGCTGCCTCCTG & 228 \\
PCNA & TGGAATCCCAGAACAGGAG & CCAATGTGGCTAAGGTCTCG & 87 \\
Col I & GCATGGCCAAGAAGACATCC & CCTCGGGTTTCCACGTCTC & 83 \\
Runx-2 & GCCGGGAATGATGAGAACTA & TGGGGAGGATTTGTGAAGAC & 155 \\
\hline
\end{tabular}

\section{Materials and Methods}

2.1. Materials. Osteoblastic MC3T3-E1 cells were purchased from the Cell Bank of the Chinese Academy of Sciences (Shanghai, China). Fetal bovine serum (FBS) and $\alpha$ minimum essential medium ( $\alpha$-MEM) were purchased from Gibco Life Technologies Co. (Carlsbad, CA, USA). 3-(4,5Dimethylthiazol-2-yl)-2,5-diphenyltetrazolium bromide (MTT), LiCl, propidium iodide (PI), and $4^{\prime}, 6$-diamidine$2^{\prime}$-phenylindole dihydrochloride (DAPI) were bought from Sigma Aldrich (Kansas, MO, USA). $\gamma$-Tocotrienol was purchased from Cayman Chemical Co. (Ann Arbor, MI, USA). Alizarin Red staining reagent kit was purchased from GenMed Scientifics Inc. (USA). ALP reagent kit and ELISA kit were bought from Nanjing Jiancheng Bioengineering Institute (Nanjing, China). The MiniBEST Universal RNA extraction kit and PrimeScript ${ }^{\mathrm{TM}}$ RT reagent kits were purchased from Takara Biotech Co., Ltd. (Dalian, China). Rabbit polyclonal antibodies for NAPDH, PCNA, and Runx2 and goat anti-rabbit secondary antibody were bought from Santa Cruz Biotechnology (Santa Cruz, CA, USA).

2.2. Cell Culture. Cells were cultured in $\alpha$-MEM containing $10 \% \mathrm{FBS}$ at $37^{\circ} \mathrm{C}$ in a humidified atmosphere containing $5 \%$ $\mathrm{CO}_{2}$. When the cells reached subconfluence (about $24 \mathrm{~h}$ ), various concentrations of $\gamma$-tocotrienol were added to the medium containing 5\% FBS. Stock solutions of $\gamma$-tocotrienol were prepared in absolute ethanol and stored at $-20^{\circ} \mathrm{C}$. The final ethanol concentration in all cultures was $0.05 \%$.

2.3. Viability Assay. The effect of $\gamma$-tocotrienol on cell proliferation was investigated by MTT assay as previously described with some modifications [30]. Briefly, MC3T3-E1 cells $\left(1 \times 10^{4}\right.$ cells/well $)$ were seeded in the 96-well plates overnight. The medium was removed and the cells were treated with $200 \mu \mathrm{L}$ of medium containing $\gamma$-tocotrienol (1, $2,4,8$, and $16 \mu \mathrm{mol} / \mathrm{L}$, resp.) for 24,48 , and $72 \mathrm{~h}$. Each dose of $\gamma$-tocotrienol was repeated in five wells. Twenty microliters of MTT ( $5 \mathrm{mg} / \mathrm{ml}$ in PBS) was added to each well and incubated at $37^{\circ} \mathrm{C}$ for $4 \mathrm{~h}$. The medium was carefully removed and $150 \mu \mathrm{L}$ of dimethyl sulfoxide was added to each well. The plates were shaken for $10 \mathrm{~min}$ and the absorbance at $490 \mathrm{~nm}$ was measured in a microplate reader (BioTek Instruments, Inc., USA). The cell viability was indicated as the percentage of the OD of samples to that of the control group, taking the viability of the blank control cells as $100 \%$.

2.4. Morphologic Observation. After treatment with various concentrations of $\gamma$-tocotrienol for the desired time, cell morphological changes were observed by inverted microscope. Changes of the nuclei were investigated by staining the cells with fluorescent DNA-binding dyes. Briefly, cells were harvested, washed with PBS, and fixed with $4 \%$ polyoxymethylene for $20 \mathrm{~min}$ at $4^{\circ} \mathrm{C}$. After washing with PBS, cells were incubated with DAPI $(15 \mu \mathrm{g} / \mathrm{ml})$ for $15 \mathrm{~min}$ in the dark at room temperature. Images were taken using a fluorescence microscope (Eclipse 80i, Nikon, Japan).

2.5. Cell Cycle Analysis. The cells were harvested, washed three times with PBS, fixed with $70 \%$ cool ethanol for $2 \mathrm{~h}$, and stained with PI solution $(500 \mu \mathrm{L}, 50 \mu \mathrm{g} / \mathrm{ml} \mathrm{PI}$, and $50 \mu \mathrm{g} / \mathrm{ml}$ RNase in 1\% NP-40 solution) for $30 \mathrm{~min}$ in the dark at room temperature. Cells $\left(1 \times 10^{5}\right)$ were analyzed by FAC Sort flow cytometer (BD Biosciences, USA). The proportions in $\mathrm{G}_{0} / \mathrm{G}_{1}$, $\mathrm{S}$, and $\mathrm{G}_{2} / \mathrm{M}$ phases were analyzed using ModFit LT analysis software.

2.6. Quantitative Real-Time $q P C R$. Total RNAs were extracted from each treatment using MiniBEST Universal RNA Extraction kit according to the manufacturer's instruction. Total RNA was reverse transcribed into cDNA using PrimeScript ${ }^{\mathrm{TM}}$ RT reagent kits, following the manufacturer's instruction. Target gene expression was normalized to the housekeeping gene glyceraldehyde-3-phosphate dehydrogenase (GAPDH). The $2^{-\Delta \Delta \mathrm{Ct}}$ method was applied to calculate relative gene expression when compared to the control group [31]. The primers [32-35] used for real-time PCR were listed in Table 1.

2.7. Western Blot Analysis. Protein expression levels were investigated by Western blot method according to our previous study [36]. The total protein concentrations of each sample were measured in a 550 Universal microplate reader (Bio-Tek Instruments, Inc.) at $562 \mathrm{~nm}$. For Western blotting, $100 \mu \mathrm{g}$ of protein was resolved on $10 \%$ polyacrylamide gels and transferred to a nitrocellulose membrane. The membrane was blocked in blocking buffer (1\% BSA, 1\% Tween 20 in $20 \mathrm{mM}$ Tris-buffered saline (TBS), $\mathrm{pH} 7.6$ ) for $30 \mathrm{~min}$ at $37^{\circ} \mathrm{C}$ in a hybridization oven, incubated with appropriate monoclonal or polyclonal primary antibody in blocking buffer for $2 \mathrm{~h}$ at $37^{\circ} \mathrm{C}$ or overnight at $4^{\circ} \mathrm{C}$. The membrane was washed $3 \times 5$ times with Tris-buffered saline Tween 20 (TBST) followed by incubation with anti-mouse or antirabbit secondary antibody at $37^{\circ} \mathrm{C}$ for $1 \mathrm{~h}$. The membrane was washed $3 \times 5$ times with TBST and then washed with TBS twice. Then the membrane was incubated with alkaline phosphatase until an appropriate signal level was obtained. 
Protein bands were detected by FluorChem Imaging Systems (Bio-Rad, Hercules, CA, USA).

2.8. ALP Activity Assay. Cells were exposed to different concentrations of $\gamma$-tocotrienol $(2,4,8$, and $16 \mu \mathrm{mol} / \mathrm{L})$ for 24,48 , and $72 \mathrm{~h}$. Cells were harvested and incubated with $1 \%$ Triton-100 in PBS. ALP activity was measured by ALP assay kit according the manufacturer's instruction. The protein was also measured by the bicinchoninic acid (BCA) method (Applygen Technologies, Inc.). ALP activity was standardized as the relative percentage to control group.

2.9. OC, ON, and Col I ELISA Assays. After exposure to different concentrations of $\gamma$-tocotrienol $(2,4,8$, and $16 \mu \mathrm{mol} / \mathrm{L}$ ) for 3 and $6 \mathrm{~d}, \mathrm{OC}, \mathrm{ON}$, and Col I secretion were evaluated in the cultured medium by ELISA kit, according to manufacturer's instructions. The absorbance was measured at $450 \mathrm{~nm}$ with a microplate reader (Eon, Bio-Tek Instruments, USA).

2.10. Mineralization Analysis by Alizarin Red Staining. After being exposed to $\gamma$-tocotrienol $(2,4,8$, and $16 \mu \mathrm{mol} / \mathrm{L})$ for 8,16 , and $24 \mathrm{~d}$, cells were stained with Alizarin Red kit (GenMed Scientifics Inc., USA). Cells with orange red staining indicated calcium deposits. The results were observed with a phase contrast microscope at a magnification of $\times 200$. Alizarin Red was quantified in a solution of $20 \%$ methanol and $10 \%$ acetic acid in water. After washing the cells for $15 \mathrm{~min}$, the solution was transferred to a 96-well plate and absorbance of Alizarin Red was measured by a spectrophotometer at $450 \mathrm{~nm}$.

2.11. Statistical Analysis. Statistical analysis was performed using SPSS version 14.0 (SPSS, Inc., Chicago, IL, USA). The data were expressed as mean $\pm \mathrm{SD}$. Differences between the control and treated groups were evaluated by the one-way analysis of variance (ANOVA) test with the Bonferroni post hoc multiple comparisons and considered significant at $p<$ 0.05 .

\section{Results and Discussions}

3.1. Effect of $\gamma$-Tocotrienol on the Proliferation of MC3T3-E1 Cells. The effect of $\gamma$-tocotrienol on cell viability was shown in Figure 1(b). Cell viability was increased significantly in $\gamma$ tocotrienol (1-8 $\mu \mathrm{mol} / \mathrm{L}$, especially at $4 \mu \mathrm{mol} / \mathrm{L})$ groups when compared to control groups. After treatment with $4 \mu \mathrm{mol} / \mathrm{L}$ $\gamma$-tocotrienol for 24,48 , and $72 \mathrm{~h}$, cell viability increased by $83.3 \%, 40.9 \%$, and $33.3 \%$, respectively $(p<0.05)$. However, cell viability was significantly inhibited by $\gamma$-tocotrienol at dosages above $16 \mu \mathrm{mol} / \mathrm{L}(p<0.05)$. Morphological changes of control and treated cells are shown in Figure 1(c). In control cells, irregular shapes were observed, such as triangles, polygons, and long spindles with different length pseudopodia. The cytoplasm was abundant and clear, and the nuclei were large and clear. There was no significant morphological change in cells treated with $\gamma$-tocotrienol at doses of 4-8 $\mu \mathrm{mol} / \mathrm{L}$ for 24,48 , and $72 \mathrm{~h}$. However, MC3T3E1 cells treated with $\gamma$-tocotrienol at doses above $16 \mu \mathrm{mol} / \mathrm{L}$ for 48 and $72 \mathrm{~h}$ began to show deformation, shrinking, and floating when compared with the control cells. The nuclear morphological alteration of MC3T3-E1 cells was shown in Figure $1(\mathrm{~d})$; there were no nuclear morphological alteration between control cells and $\gamma$-tocotrienol- $(2-8 \mu \mathrm{mol} / \mathrm{L})$ treated cells. However, typically apoptotic changes such as chromatin condensation and nuclear fragmentation were found in cells treated with $\gamma$-tocotrienol at $16 \mu \mathrm{mol} / \mathrm{L}$ for $72 \mathrm{~h}$ or $32 \mu \mathrm{mol} / \mathrm{L}$ for both 48 and $72 \mathrm{~h}$ (data not shown).

Treatment with $\gamma$-tocotrienol $(2-8 \mu \mathrm{mol} / \mathrm{L})$ for 24 and $48 \mathrm{~h}$ did not change the ratios of G0/G1, S, and G2/M phase in MC3T3-E1 cells when compared to the control cells (Figure 2(a)). However, it was significantly affected if the dose of $\gamma$-tocotrienol was more than $16 \mu \mathrm{mol} / \mathrm{L}$. The proportion in $\mathrm{G}_{0} / \mathrm{G}_{1}$ phase was changed from 57.85 to $64.61 \%$ in untreated cells and from 85.74 to $80.08 \%$ in treated cells for 24 and $48 \mathrm{~h}$, respectively, while $\mathrm{S}$ phase was changed from 31.26 to $25.63 \%$ in the control cells and from 6.34 to $11.46 \%$ in treated cells for 24 and $48 \mathrm{~h}$, respectively. The apoptotic rates were $4.55 \% \pm 0.72 \%$ and $14.26 \% \pm 1.91 \%$ in cells treated with $\gamma$-tocotrienol $(16 \mu \mathrm{mol} / \mathrm{L})$ for 24 and $48 \mathrm{~h}$, respectively. Our results showed that $\gamma$-tocotrienol $(2-8 \mu \mathrm{mol} / \mathrm{L})$ could promote osteoblast proliferation did not affect the cell cycle distribution, and no cytotoxicity was observed in MC3T3-E1 cells. However, $16 \mu \mathrm{mol} / \mathrm{L}$ and above of $\gamma$-tocotrienol showed the toxicity to osteoblast cells. The results are consistent with previous studies $[16,37]$ which demonstrate that $\gamma$ tocotrienol, at low dosage, was better than $\alpha$-tocopherol in protecting rat osteoblasts against $\mathrm{H}_{2} \mathrm{O}_{2}$ toxicity; but at high dosage it was toxic to osteoblasts in rats [16]. It may be caused by the fact that antioxidants, like $\gamma$-tocotrienol, at a certain dosage can become prooxidants [38]. The unsaturated side chains of tocotrienols (Figure 1(a)) allow them to penetrate more efficiently into the membrane lipid bilayer resulting in a high antioxidant activity in comparison with tocopherols [39].

PCNA, a nuclear protein that binds to DNA polymerase, is a cell cycle regulator expressed in the nucleus of proliferating cells. PCNA is an accepted hallmark for cellular proliferation $[40,41]$. Ki-67, a protein expressed in proliferating cells, may indicate a more robust marker of cell proliferation than PCNA [16]. Ki-67 protein expression occurs during the $G_{1}$ phase, increases during the cycle cell, and rapidly declines after mitosis [42]. To further determine effects of $\gamma$-tocotrienol on the proliferation of MC3T3-E1 cells, levels of Ki-67 and PCNA were determined by real-time PCR and Western blot. The results were shown in Figures 2(b) and 2(c); mRNA levels of Ki-67 and PCNA were obviously upregulated by treatment with $2-8 \mu \mathrm{mol} / \mathrm{L}$ of $\gamma$-tocotrienol for 48 and $72 \mathrm{~h}$. However, they were downregulated in cells treated with $16 \mu \mathrm{mol} / \mathrm{L}$ of $\gamma$-tocotrienol. Furthermore, treatment with $2-4 \mu \mathrm{mol} / \mathrm{L}$ of $\gamma$-tocotrienol for 24 and $48 \mathrm{~h}$ significantly increased the PCNA protein expression level in MC3T3-E1 in comparison with the control group. However, $16 \mu \mathrm{mol} / \mathrm{L}$ $\gamma$-tocotrienol decreased the expressive level of PCNA protein (Figure 2(d)). The result indicated that $\gamma$-tocotrienol at low dosage could indirectly regulate the activation of osteoblast proliferation and was consistent with MTT results. 


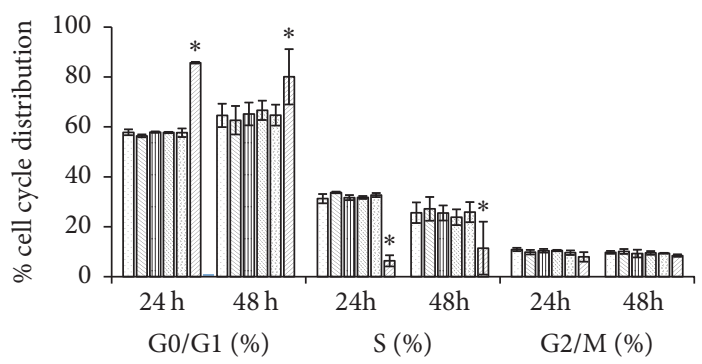

$$
\begin{array}{ll}
\square \mathrm{B} & \square 4 \mu \mathrm{mol} / \mathrm{L} \\
\square \mathrm{C} & \square 8 \mu \mathrm{mol} / \mathrm{L} \\
\text { 四 } 2 \mu \mathrm{mol} / \mathrm{L} & \square 16 \mu \mathrm{mol} / \mathrm{L}
\end{array}
$$

(a)

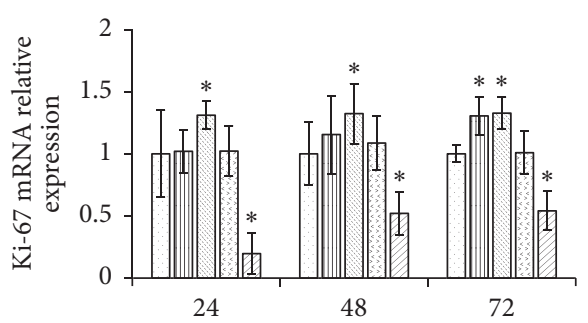

(h)

$$
\begin{array}{ll}
\square 0 \mu \mathrm{mol} / \mathrm{L} & \square 8 \mu \mathrm{mol} / \mathrm{L} \\
\square 2 \mu \mathrm{mol} / \mathrm{L} & \square 16 \mu \mathrm{mol} / \mathrm{L}
\end{array}
$$$$
\text { 암 } 4 \mu \mathrm{mol} / \mathrm{L}
$$

(b)

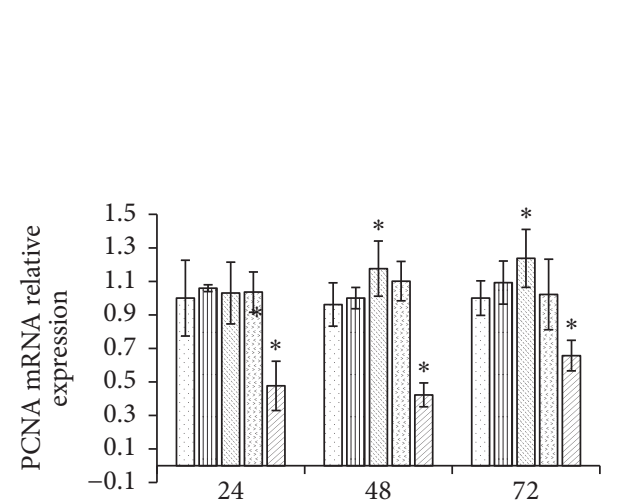

(h)

$$
\begin{array}{ll}
\square 0 \mu \mathrm{mol} / \mathrm{L} & \square 8 \mu \mathrm{mol} / \mathrm{L} \\
\square 2 \mu \mathrm{mol} / \mathrm{L} & \square 16 \mu \mathrm{mol} / \mathrm{L} \\
\square 4 \mu \mathrm{mol} / \mathrm{L} &
\end{array}
$$

(c)
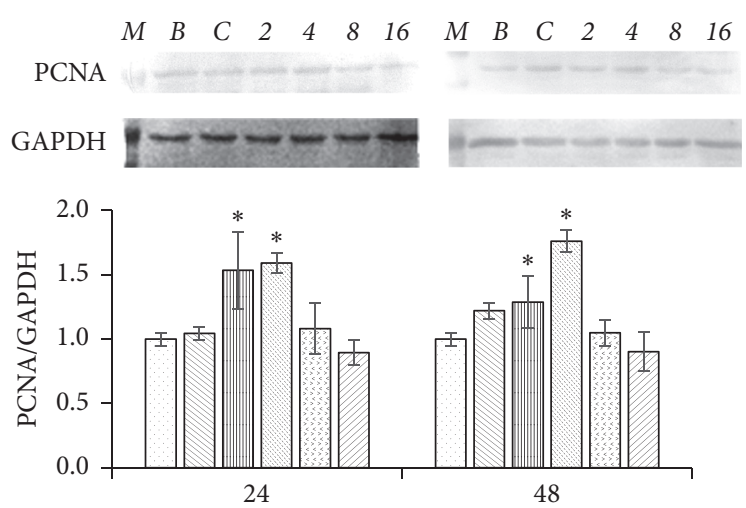

(h)

$$
\begin{array}{ll}
\square \text { Blank control } & \square 4 \mu \mathrm{mol} / \mathrm{L} \\
\square \text { Ethanol control } & \square 8 \mu \mathrm{mol} / \mathrm{L} \\
\square 2 \mu \mathrm{mol} / \mathrm{L} & \square 16 \mu \mathrm{mol} / \mathrm{L}
\end{array}
$$

(d)

FIGURE 2: Effect of $\gamma$-tocotrienol on cell cycle progression, relative mRNA, and protein levels of Ki67 and PCNA in MC3T3-E1 cells. (a) Cells were treated with different doses of $\gamma$-tocotrienol for 24 and $48 \mathrm{~h}$. Cells were fixed by $70 \%$ ethanol and stained by propidium iodide dye. The distribution of cell cycle was determined by flow cytometry. ((b), (c)) Cells were treated with different doses of $\gamma$-tocotrienol (2, 4, 8 , and $16 \mu \mathrm{mol} / \mathrm{L}$ ) for the desired time. mRNA levels of Ki67 and PCNA were determined by real-time PCR. (d) Protein levels of PCNA were determined by Western blot. Data are expressed as mean $\pm \mathrm{SD}(n=3) .{ }^{*} p<0.05$, compared to the control group. M: marker; B: blank control; C: ethanol control.

3.2. Effect of $\gamma$-Tocotrienol on the Differentiation of MC3T3E1 Cells. ALP is a homodimeric glycoprotein secreted by osteoblasts, and the degree of secretion is related to the degree of differentiation of the osteoblasts [43]. ALP secretion is enhanced along with the process of osteoblasts differentiation [44]. Therefore, the appearance of ALP activity is an early phenotypic marker for osteogenic differentiation of osteoblasts. In this study, ALP activity in MC3T3-E1 cells treated with $\gamma$-tocotrienol for $24 \mathrm{~h}$ and $48 \mathrm{~h}$ did not significantly change (data not shown here). However, it was significantly increased from $15 \%$ to $194 \%$ in cells treated with $\gamma$-tocotrienol at $4-16 \mu \mathrm{mol} / \mathrm{L}$ for $72 \mathrm{~h}$, when compared to the control group (Figure 3(a)). Furthermore, ALP activity in cells treated with $4 \mu \mathrm{mol} / \mathrm{L}$ of $\gamma$-tocotrienol for $72 \mathrm{~h}$ was significantly increased 1.55 -fold when compared with control cells $(p<0.05)$. The results suggested that $\gamma$-tocotrienol could promote osteoblast differentiation.

$\mathrm{OC}, \mathrm{ON}, \mathrm{Col} \mathrm{I}$, and Runx2 are major phenotypic markers for preosteoblast differentiation during bone formation. OC is the most specific gene for the osteoblast differentiation and mineralization. OC is expressed during the postproliferative period and reaches its maximum expression during mineralization and accumulates in the mineralized bone [45]. $\mathrm{ON}$ is synthesized by cells of the osteoblastic lineage, and it also is a differentiation marker of bone cells [46]. Col I, an important component of the bone extracellular matrix, has been shown to be involved in the differentiation of the osteoblast phenotype [47]. $\mathrm{LiCl}$ is able to increase osteoblast differentiation [48]; thus it was used as a positive control. In this study, the secretion levels of $\mathrm{OC}$ and $\mathrm{ON}$ in the supernatants were shown in Figures 3(b) and 3(c). The treatment with $\gamma$-tocotrienol $(2-8 \mu \mathrm{mol} / \mathrm{L})$ for $3 \mathrm{~d}$ and $6 \mathrm{~d}$ obviously increased the secretion levels of both OC and ON in MC3T3E1 cells. The maximal effect was observed in MC3T3-E1 cells treated with $4 \mu \mathrm{mol} / \mathrm{L}$ of $\gamma$-tocotrienol, which increased OC and $\mathrm{ON}$ secretion levels by $161.45 \%$ and $58.05 \%$ for $3 \mathrm{~d}$ and $122.97 \%$ and $69.77 \%$ for $6 \mathrm{~d}$, respectively. Meanwhile, the Col I mRNA levels in cells treated with $2-8 \mu \mathrm{mol} / \mathrm{L}$ of $\gamma$-tocotrienol 


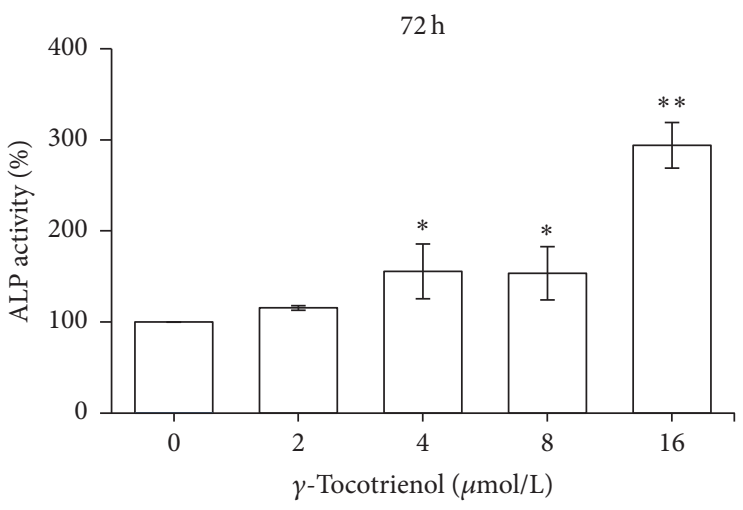

(a)

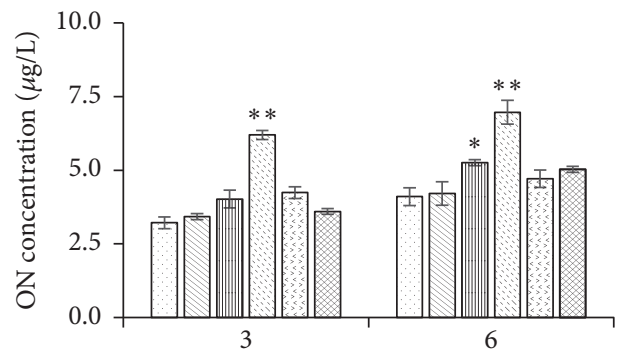

(d)

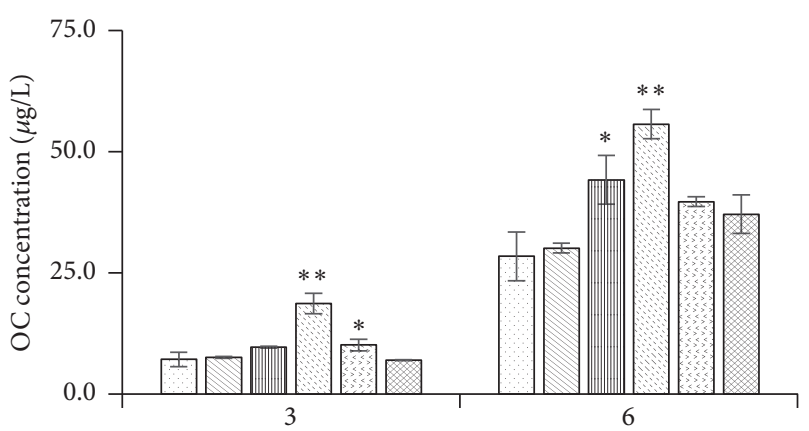

(d)
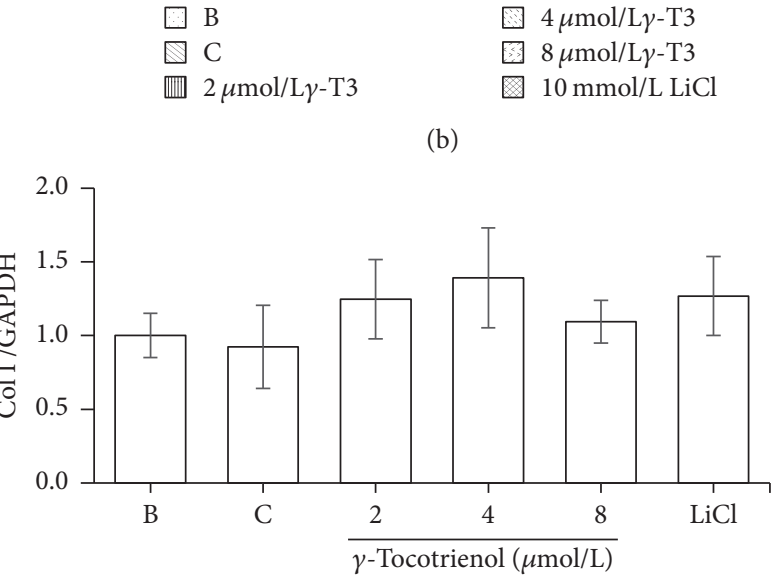

$\begin{array}{ll}\square \mathrm{B} & \text { 図 } 4 \mu \mathrm{mol} / \mathrm{L} \gamma-\mathrm{T} 3 \\ \square \mathrm{C} & 8 \mu \mathrm{mol} / \mathrm{L} \gamma-\mathrm{T} 3 \\ \text { 血 } 2 \mu \mathrm{mol} / \mathrm{L} \gamma \text {-T3 } & \text { 图 } 10 \mathrm{mmol} / \mathrm{L} \mathrm{LiCl}\end{array}$

(c)

(d)

Figure 3: Effect of $\gamma$-tocotrienol on the differentiation in MC3T3-E1 cells. Cells were treated with $\gamma$-tocotrienol at different doses for the desired time. The ALP activity (a), OC and ON amount ((b), (c)), and Col I mRNA level (d) were determined by colorimetric analysis, ELISA, and real-time PCR analysis, respectively. Data are expressed as mean $\pm \mathrm{SD}(n=3) .{ }^{*} p<0.05$ and ${ }^{* *} p<0.01$, compared to the control group. B: blank control; C: ethanol control.

for $3 \mathrm{~d}$ were obviously increased compared with the control cells (Figure 3(d)), and its protein level did not change in comparison with the control cells (data not shown). The result further confirmed that $\gamma$-tocotrienol at low dosage can stimulate osteoblast differentiation, and it also showed that $\gamma$ tocotrienol may contribute to the mineralization. In addition, other findings indicate that $\gamma$-tocotrienols delivered through nanoemulsion exhibit superior antioxidant properties and osteoblast differentiation [49], which is consistent with our findings.

Runx2, a member of the runt family of transcription factors, is important for osteoblast differentiation [50,51]. In Runx2 knockout mice, no bone tissues or osteoblasts are generated, which indicates that osteoblast differentiation is completely blocked in the absence of Runx2 [52]. The results showed that both the mRNA and protein level of Runx2 (Figures 4(a) and 4(b)) were obviously upregulated in MC3T3-E1 cells treated with 4 and $8 \mu \mathrm{mol} / \mathrm{L}$ of $\gamma$ tocotrienol for $72 \mathrm{~h}$ when compared with the control cells $(p<0.05)$, which demonstrated that $\gamma$-tocotrienol promoted osteoblast differentiation by upregulation of the expression of Runx2.

3.3. Effect of $\gamma$-Tocotrienol on the Mineralization in Osteoblastic MC3T3-E1 Cells. Mineralization, an indispensable process for bone formation, occurs in the last stage following collagenous matrix maturation. It is a functional performance of the further differentiation and maturation of the cells. Osteoblasts are the main functional cells that promote bone mineralization. Mineralized nodule formation is a symbol of differentiation and maturation of osteoblasts and a morphological manifestation of osteogenesis [53]. In order to further clarify the effect of $\gamma$-tocotrienol on mineralization of osteoblasts, the level of mineralized nodule was observed by using Alizarin Red staining method. The quantities of Alizarin Red were analyzed by measuring the absorbance at $450 \mathrm{~nm}$. As shown in Figure 5(a), the mineralized nodule formation was lower in the control group. The number of mineralized nodules was significantly increased in cells treated with $2-8 \mu \mathrm{mol} / \mathrm{L}$ of $\gamma$-tocotrienol for 24 days. The 


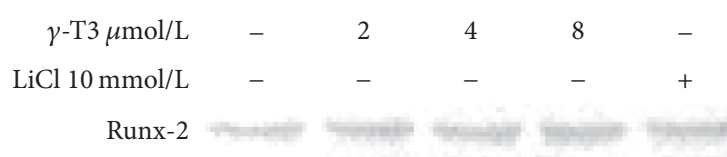

\section{GAPDH}

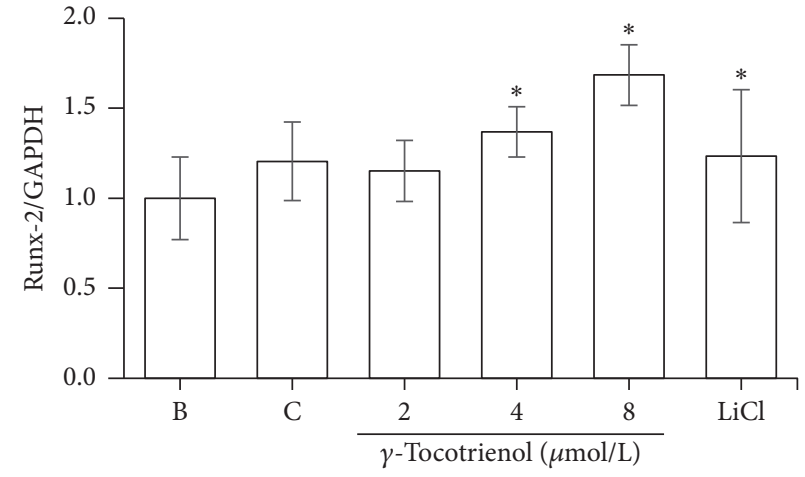

(a)

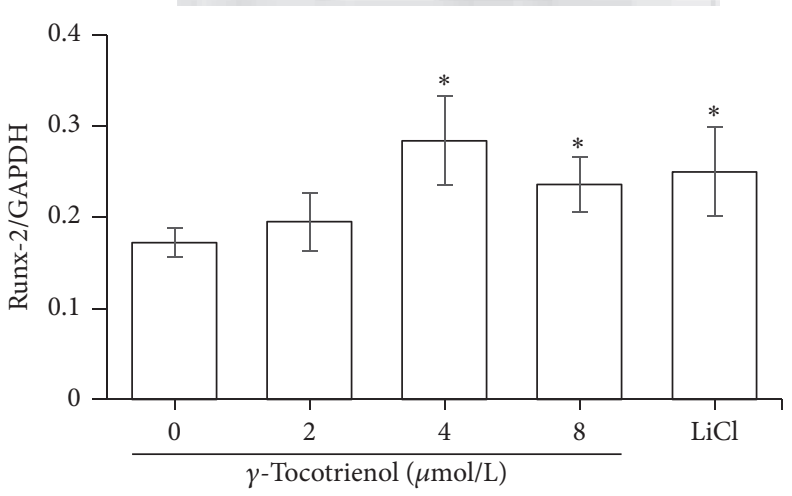

(b)

FIGURE 4: Effect of $\gamma$-tocotrienol on mRNA and protein levels of Runx2 in MC3T3-E1 cells. Cells were treated with different doses of $\gamma$ tocotrienol for $72 \mathrm{~h}$. The mRNA (a) and protein expression (b) of Runx2 were determined by real-time PCR and Western blot. Data are expressed as mean $\pm \mathrm{SD}(n=3) .{ }^{*} p<0.05$, compared to the control group. B: blank control; C: ethanol control.

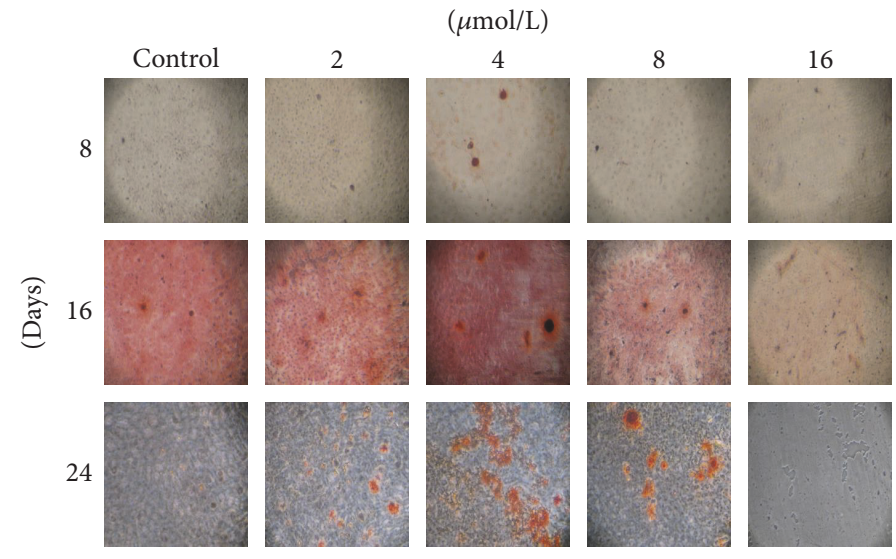

(a)

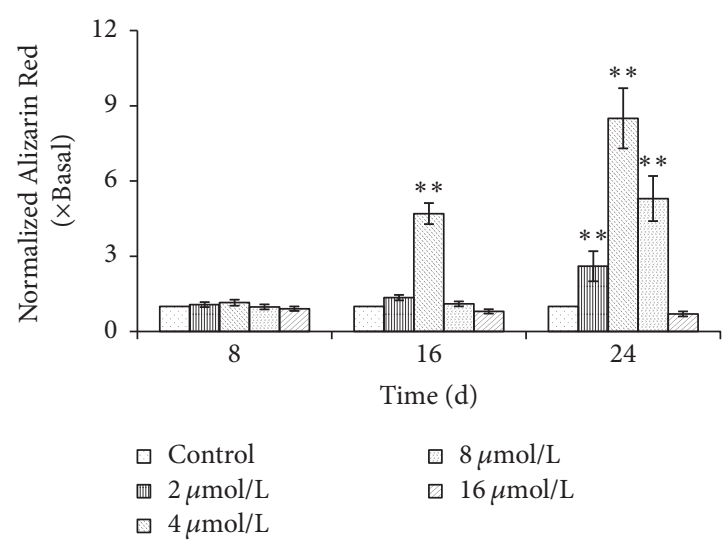

(b)

FIGURE 5: Effects of $\gamma$-tocotrienol on the mineralization in MC3T3-E1 cells. Cells treated with different doses of $\gamma$-tocotrienol for the desired time. The mineralization in cells was determined by Alizarin Red staining. (a) Formation of mineralized nodule (100x). (b) Alizarin Red was quantified by spectrophotometer. The results are expressed as means $\pm \mathrm{SD}(n=3) .{ }^{* *} p<0.01$, compared to the control group.

formation of mineralized nodules was increased over 2.5-fold in cells treated with $\gamma$-tocotrienol at low concentration for $24 \mathrm{~d}$ compared with the control group (Figure 5(b)). No cells could be observed in the $16 \mu \mathrm{mol} / \mathrm{L}$ tocotrienol-treated group, which indicated that treatment with $16 \mu \mathrm{mol} / \mathrm{L}$ tocotrienol for 8 days or longer time showed a strong toxicity and inhibitory effect on the mineralization of osteoblast. Our results suggest that $\gamma$-tocotrienol at low doses $(2-8 \mu \mathrm{mol} / \mathrm{L})$ has a role in promoting mineralization and inhibits bone formation at doses of $16 \mu \mathrm{mol} / \mathrm{L}$ or over.

\section{Conclusions}

In summary, the data in this study showed that $\gamma$-tocotrienol $(2-8 \mu \mathrm{mol} / \mathrm{L})$ could promote the proliferation, differentiation, and mineralized nodule formation in MC3T3-E1 cells. Meanwhile, our data also indicated that Runx2 protein may be involved in the effect of $\gamma$-tocotrienol on bone formation through osteoblastic differentiation and subsequent mineralization. $\gamma$-Tocotrienol was effective for stimulating osteoblast bone formation and it might be useful for prevention of osteoporosis. However, the exact mechanism of $\gamma$-tocotrienol 
on proliferation and differentiation of osteoblasts needs further investigation.

\author{
Abbreviations \\ Ki-67: Ki-67 antigen \\ PCNA: Proliferating cell nuclear antigen \\ MTT: 3-(4,5-Dimethylthiazol-2-yl)-2,5- \\ diphenyltetrazolium \\ bromide \\ OC: Osteocalcin \\ ON: Osteonectin \\ ALP: Alkaline phosphatase \\ Col I: Collagen type I.
}

\section{Conflicts of Interest}

Authors declare that there are no conflicts of interest regarding the publication of this paper.

\section{Acknowledgments}

This project was supported by the National Natural Science Foundation of China (no. 31501481 and no. 81402666).

\section{References}

[1] S. Khosla, J. J. Westendorf, and M. J. Oursler, "Building bone to reverse osteoporosis and repair fractures," The Journal of Clinical Investigation, vol. 118, no. 2, pp. 421-428, 2008.

[2] Y.-C. Lu, Y. C. Lin, Y.-K. Lin et al., "Prevalence of osteoporosis and low bone mass in older chinese population based on bone mineral density at multiple skeletal sites," Scientific Reports, vol. 6, Article ID 25206, 2016.

[3] P. Sambrook and C. Cooper, “Osteoporosis," The Lancet, vol. 367, no. 9527, pp. 2010-2018, 2006.

[4] H. Hoshino, M. Takahashi, K. Kushida, T. Ohishi, and T. Inoue, "The relationships between the degree of $\beta$-isomerization of type I collagen degradation products in the urine and aging, menopause and osteoporosis with fractures," Osteoporosis International, vol. 9, no. 5, pp. 405-409, 1999.

[5] I. R. Reid, "Anti-resorptive therapies for osteoporosis," Seminars in Cell \& Developmental Biology, vol. 19, no. 5, pp. 473-478, 2008.

[6] G. A. Rodan and T. J. Martin, "Therapeutic approaches to bone diseases," Science, vol. 289, no. 5484, pp. 1508-1514, 2000.

[7] B. L. Riggs and A. M. Parfitt, "Drugs used to treat osteoporosis: the critical need for a uniform nomenclature based on their action on bone remodeling," Journal of Bone and Mineral Research, vol. 20, no. 2, pp. 177-184, 2005.

[8] N. E. Lane and A. Kelman, "Review of anabolic therapies for osteoporosis," Arthritis Research \& Therapy, vol. 5, pp. 214-222, 2003.

[9] P. Ducy, T. Schinke, and G. Karsenty, "The osteoblast: a sophisticated fibroblast under central surveillance," Science, vol. 289, no. 5484, pp. 1501-1504, 2000.

[10] L. Packer, S. U. Weber, and G. Rimbach, "Molecular aspects of alpha-tocotrienol antioxidant action and cell signalling," Journal of Nutrition, vol. 131, pp. 369S-373S, 2001.
[11] P. J. McLaughlin and J. L. Weihrauch, "Vitamin E content of foods," Journal of The American Dietetic Association, vol. 75, pp. 647-665, 1979.

[12] N. Miyoshi, Y. Wakao, S. Tomono, M. Tatemichi, T. Yano, and H. Ohshima, "The enhancement of the oral bioavailability of gamma-tocotrienol in mice by gamma-cyclodextrin inclusion," The Journal of Nutritional Biochemistry, vol. 22, no. 12, pp. 11211126, 2011.

[13] A. S. Nazrun, M. Norazlina, M. Norliza, and S. Ima Nirwana, "Comparison of the effects of tocopherol and tocotrienol on osteoporosis in animal models," International Journal of Pharmacology, vol. 6, no. 5, pp. 561-568, 2010.

[14] M. Z. Mehat, A. N. Shuid, N. Mohamed, N. Muhammad, and I. N. Soelaiman, "Beneficial effects of vitamin e isomer supplementation on static and dynamic bone histomorphometry parameters in normal male rats," Journal of Bone and Mineral Metabolism, vol. 28, no. 5, pp. 503-509, 2010.

[15] M. Norazlina, P. L. Lee, H. I. Lukman, A. S. Nazrun, and S. Ima-Nirwana, "Effects of vitamin E supplementation on bone metabolism in nicotine-treated rats," Singapore Medical Journal, vol. 48, pp. 195-199, 2007.

[16] H. Hermizi, O. Faizah, S. Ima-Nirwana, S. Ahmad Nazrun, and M. Norazlina, "Beneficial effects of tocotrienol and tocopherol on bone histomorphometric parameters in Sprague-Dawley male rats after nicotine cessation," Calcified Tissue International, vol. 84, no. 1, pp. 65-74, 2009.

[17] N. S. Ahmad, B. A. K. Khalid, D. A. Luke, and S. I. Nirwana, "Tocotrienol offers better protection than tocopherol from free radical-induced damage of rat bone," Clinical and Experimental Pharmacology and Physiology, vol. 32, no. 9, pp. 761-770, 2005.

[18] S. Maniam, N. Mohamed, A. N. Shuid, and I. N. Soelaiman, "Palm tocotrienol exerted better antioxidant activities in bone than $\alpha$-tocopherol," Basic \& Clinical Pharmacology \& Toxicology, vol. 103, no. 1, pp. 55-60, 2008.

[19] S. Abdul-Majeed, N. Mohamed, and I.-N. Soelaiman, "The use of delta-tocotrienol and lovastatin for anti-osteoporotic therapy," Life Sciences, vol. 125, pp. 42-48, 2015.

[20] S. Ima-Nirwana, A. Kiftiah, A. G. Zainal, M. Norazlina, M. T. Gapor, and B. A. K. Khalid, "Palm vitamin E prevents osteoporosis in orchidectomized growing male rats," Natural Product Sciences, vol. 6, no. 4, pp. 155-160, 2000.

[21] M. Norazlina, S. Ima-Nirwana, M. T. Gapor, and B. A. K. Khalid, "Palm vitamin $\mathrm{E}$ is comparable to $\alpha$-tocopherol in maintaining bone mineral density in ovariectomised female rats," Experimental and Clinical Endocrinology \& Diabetes, vol. 108, no. 4, pp. 305-310, 2000.

[22] S. Ima-Nirwana and S. Suhaniza, "Effects of Tocopherols and Tocotrienols on Body Composition and Bone Calcium Content in Adrenalectomized Rats Replaced with Dexamethasone," Journal of Medicinal Food, vol. 7, no. 1, pp. 45-51, 2004.

[23] A. S. Nazrun, D. A. Luke, B. A. K. Khalid, and S. ImaNirwana, "Vitamin E protects from free-radical damage on femur of rats treated with ferric nitrilotriacetate," Current Topics in Pharmacology, vol. 9, pp. 107-115, 2005.

[24] I. N. Soelaiman, W. Ming, R. Abu Bakar et al., "Palm tocotrienol supplementation enhanced bone formation in oestrogendeficient rats," International Journal of Endocrinology, vol. 2012, Article ID 532862, 7 pages, 2012.

[25] A. N. Shuid, Z. Mehat, N. Mohamed, N. Muhammad, and I. N. Soelaiman, "Vitamin E exhibits bone anabolic actions in normal male rats," Journal of Bone and Mineral Metabolism, vol. 28, no. 2, pp. 149-156, 2010. 
[26] A. M. Nizar, A. S. Nazrun, M. Norazlina, M. Norliza, and S. Ima Nirwana, "Low dose of tocotrienols protects osteoblasts against oxidative stress," La Clinica Terapeutica, vol. 162, no. 6, pp. 533538, 2011.

[27] K.-Y. Chin and S. Ima-Nirwana, "The biological effects of tocotrienol on bone: A review on evidence from rodent models," Drug Design, Development and Therapy, vol. 9, pp. 2049-2061, 2015.

[28] P. Chiewwei, C. Yuenmay, A. N. Ma, and C. Chenghock, "The effect of physical refining on palm vitamin E (tocopherol, tocotrienol and tocomonoenol," American Journal of Applied Sciences, vol. 4, pp. 374-377, 2007.

[29] L. Deng, Y. Ding, Y. Peng et al., " $\gamma$-Tocotrienol protects against ovariectomy-induced bone loss via mevalonate pathway as HMG-CoA reductase inhibitor," Bone, vol. 67, pp. 200-207, 2014.

[30] W. Xu, M. Du, Y. Zhao, Q. Wang, W. Sun, and B. Chen, " $\gamma$ Tocotrienol inhibits cell viability through suppression of $\beta$ catenin/Tcf signaling in human colon carcinoma HT-29 cells," The Journal of Nutritional Biochemistry, vol. 23, no. 7, pp. 800807, 2012.

[31] K. J. Livak and T. D. Schmittgen, "Analysis of relative gene expression data using real-time quantitative PCR and the 2(Delta Delta C (T)) method," Methods, vol. 25, no. 4, pp. 402408, 2001.

[32] Y. Gao, Effects of icariin on the proliferation and differentiation of osteoblast and its possible mechanism of action in vitro [Ph.D. thesis], Hebei Medical University, China, 2013.

[33] A. Steinbach, A. Tautzenberger, A. Ignatius, M. Pluntke, O. Marti, and D. Volkmer, "Coatings from micropatterned sulfobetaine polymer brushes as substrates for MC3T3-E1 cells," Journal of Materials Science: Materials in Medicine, vol. 23, no. 2, pp. 573-579, 2012.

[34] M.-B. Kim, Y. Song, and J.-K. Hwang, "Kirenol stimulates osteoblast differentiation through activation of the BMP and Wnt/ $\beta$-catenin signaling pathways in MC3T3-E1 cells," Fitoterapia, vol. 98, pp. 59-65, 2014.

[35] M.-T. Tsai, D.-J. Lin, S. Huang, H.-T. Lin, and W. H. Chang, "Osteogenic differentiation is synergistically influenced by osteoinductive treatment and direct cell-cell contact between murine osteoblasts and mesenchymal stem cells," International Orthopaedics, vol. 36, no. 1, pp. 199-205, 2012.

[36] W.-L. Xu, J.-R. Liu, H.-K. Liu et al., "Inhibition of proliferation and induction of apoptosis by $\gamma$-tocotrienol in human colon carcinoma HT-29 cells," Nutrition Journal, vol. 25, no. 5, pp. 555-566, 2009.

[37] N. Abd Manan, N. Mohamed, and A. N. Shuid, "Effects of low-dose versus high-dose $\gamma$-tocotrienol on the bone cells exposed to the hydrogen peroxide-induced oxidative stress and apoptosis," Evidence-Based Complementary and Alternative Medicine, vol. 2012, Article ID 680834, 10 pages, 2012.

[38] R. Pazdro and J. R. Burgess, "The role of vitamin E and oxidative stress in diabetes complications," Mechanisms of Ageing and Development, vol. 131, no. 4, pp. 276-286, 2010.

[39] E. Serbinova, V. Kagan, D. Han, and L. Packer, "Free radical recycling and intramembrane mobility in the antioxidant properties of alpha-tocopherol and alpha-tocotrienol," Free Radical Biology \& Medicine, vol. 10, no. 5, pp. 263-275, 1991.

[40] Z. P. Barnouti, P. Owtad, G. Shen, P. Petocz, and M. A. Darendeliler, "The biological mechanisms of PCNA and BMP in TMJ adaptive remodeling.," The Angle Orthodontist, vol. 81, no. 1, pp. 91-99, 2011.
[41] S. E. Johnson and R. E. Allen, "Proliferating cell nuclear antigen (PCNA) is expressed in activated rat skeletal muscle satellite cells," Journal of Cellular Physiology, vol. 154, no. 1, pp. 39-43, 1993.

[42] D. Mccormick, H. Chong, C. Hobbs, C. Datta, and P. A. Hall, "Detection of the Ki-67 antigen in fixed and wax-embedded sections with the monoclonal antibody MIB1," Histopathology, vol. 22, no. 4, pp. 355-360, 1993.

[43] W. N. Addison, F. Azari, E. S. Sørensen, M. T. Kaartinen, and M. D. McKee, "Pyrophosphate inhibits mineralization of osteoblast cultures by binding to mineral, up-regulating osteopontin, and inhibiting alkaline phosphatase activity," The Journal of Biological Chemistry, vol. 282, no. 21, pp. 15872-15883, 2007.

[44] K. H. Wlodarski, "Properties and Origin of Osteoblasts," Clinical Orthopaedics and Related Research, vol. 252, pp. 276-293, 1990.

[45] Y.-F. Chou, J. C. Y. Dunn, and B. M. Wu, "In vitro response of MC3T3-E1 preosteoblasts within three-dimensional apatitecoated PLGA scaffolds," Journal of Biomedical Materials Research Part B: Applied Biomaterials, vol. 75, no. 1, pp. 81-90, 2005.

[46] G. Jundt, K.-H. Berghäuser, J. D. Termine, and A. Schulz, "Osteonectin-a differentiation marker of bone cells," Cell and Tissue Research, vol. 248, no. 2, pp. 409-415, 1987.

[47] M. Jagodzinski, M. Drescher, J. Zeichen et al., "Effects of cyclic longitudinal mechanical strain and dexamethasone on osteogenic differentiation of human bone marrow stromal cells," European Cells and Materials, vol. 7, pp. 35-41, 2004.

[48] P. Clement-Lacroix, M. Ai, F. Morvan et al., "Lrp5-independent activation of Wnt signaling by lithium chloride increases bone formation and bone mass in mice," Proceedings of the National Acadamy of Sciences of the United States of America, vol. 102, no. 48, pp. 17406-17411, 2005.

[49] L.-S. Song, Z.-X. Zhang, Y. Wang, Y. Liu, R. Zhang, and L.-J. $\mathrm{Lu}$, "Effects of nano-emulsion preparations of tocopherols and tocotrienols on oxidative stress and osteoblast differentiation," Archives of Biological Sciences, vol. 69, no. 1, pp. 149-156, 2017.

[50] P. Ducy, R. Zhang, V. Geoffroy, A. L. Ridall, and G. Karsenty, "Osf2/Cbfa1: a transcriptional activator of osteoblast differentiation," Cell, vol. 89, no. 5, pp. 747-754, 1997.

[51] P. Ducy, "Cbfal: A molecular switch in osteoblast biology," Developmental Dynamics, vol. 219, no. 4, pp. 461-471, 2000.

[52] K. Nakashima, X. Zhou, G. Kunkel et al., "The novel zinc fingercontaining transcription factor Osterix is required for osteoblast differentiation and bone formation," Cell, vol. 108, no. 1, pp. 1729, 2002.

[53] C. Wang, M.-X. Meng, X.-L. Tang et al., "The proliferation, differentiation, and mineralization effects of puerarin on osteoblasts in vitro," Chinese Journal of Natural Medicines, vol. 12, no. 6, pp. 436-442, 2014. 

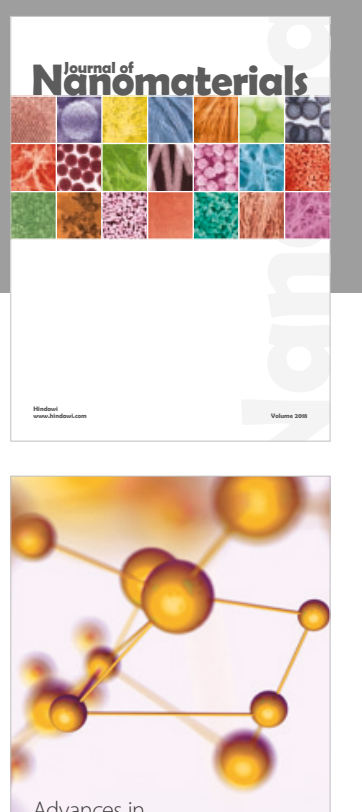

Physical Chemistry
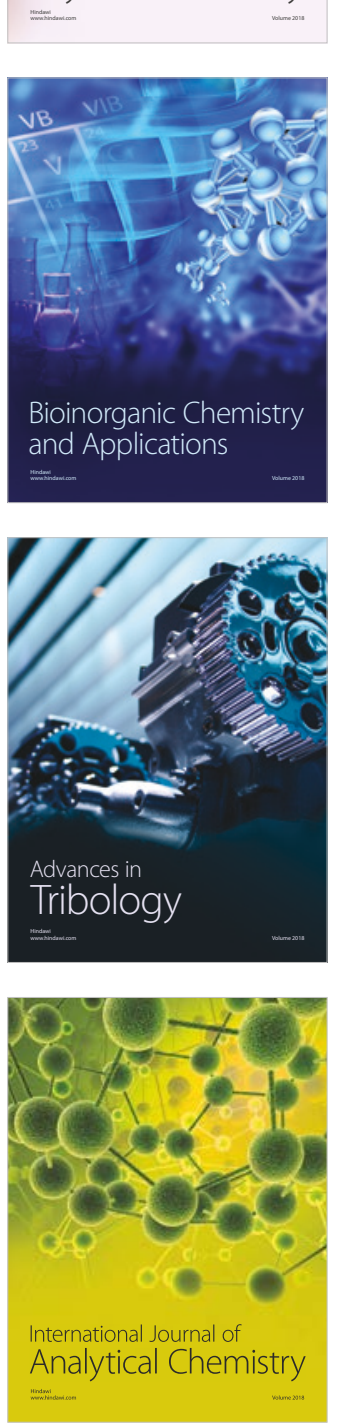

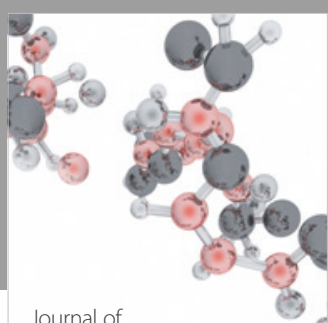

Analytical Methods

in Chemistry

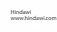

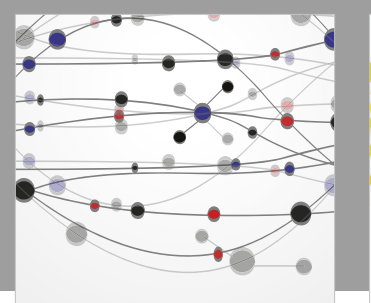

The Scientific World Journal

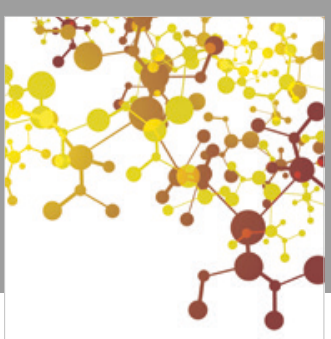

Journal of

Applied Chemistry
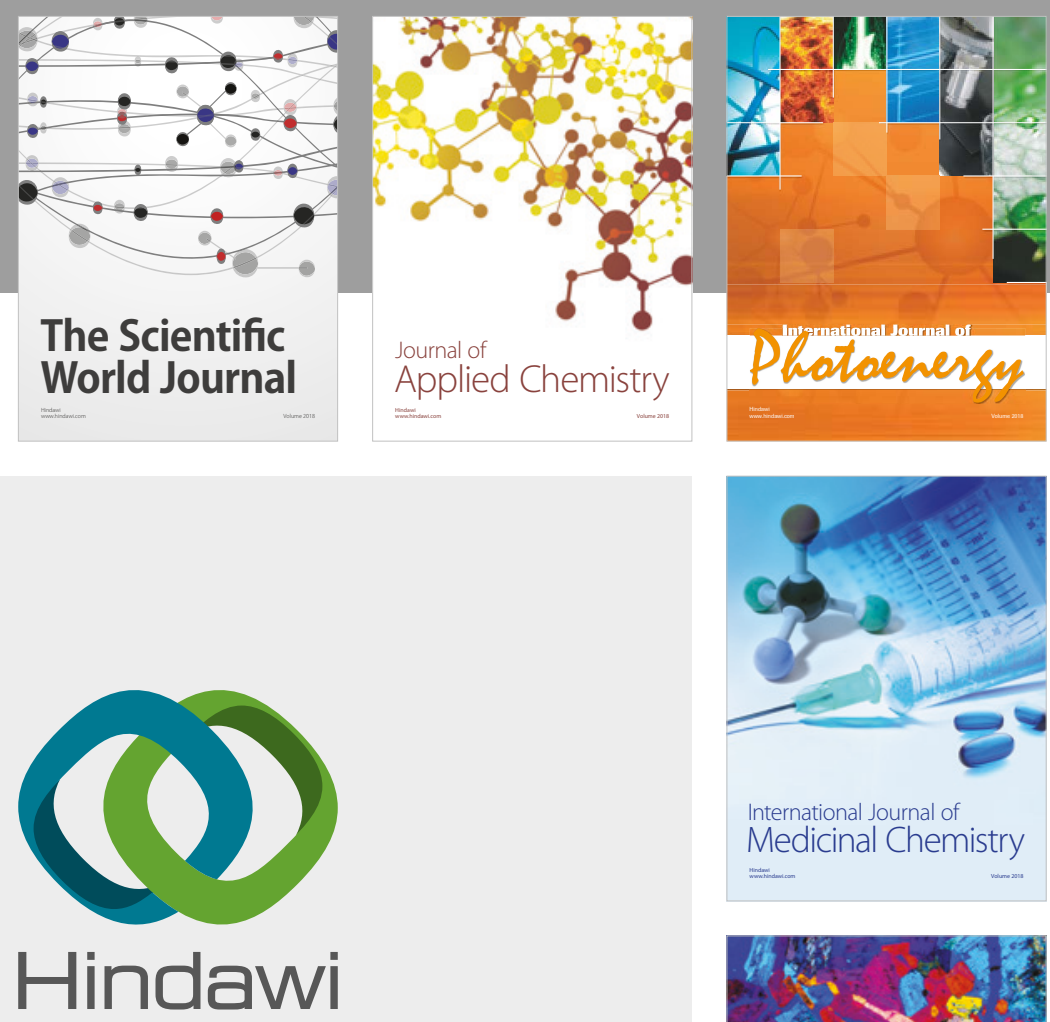

Submit your manuscripts at

www.hindawi.com
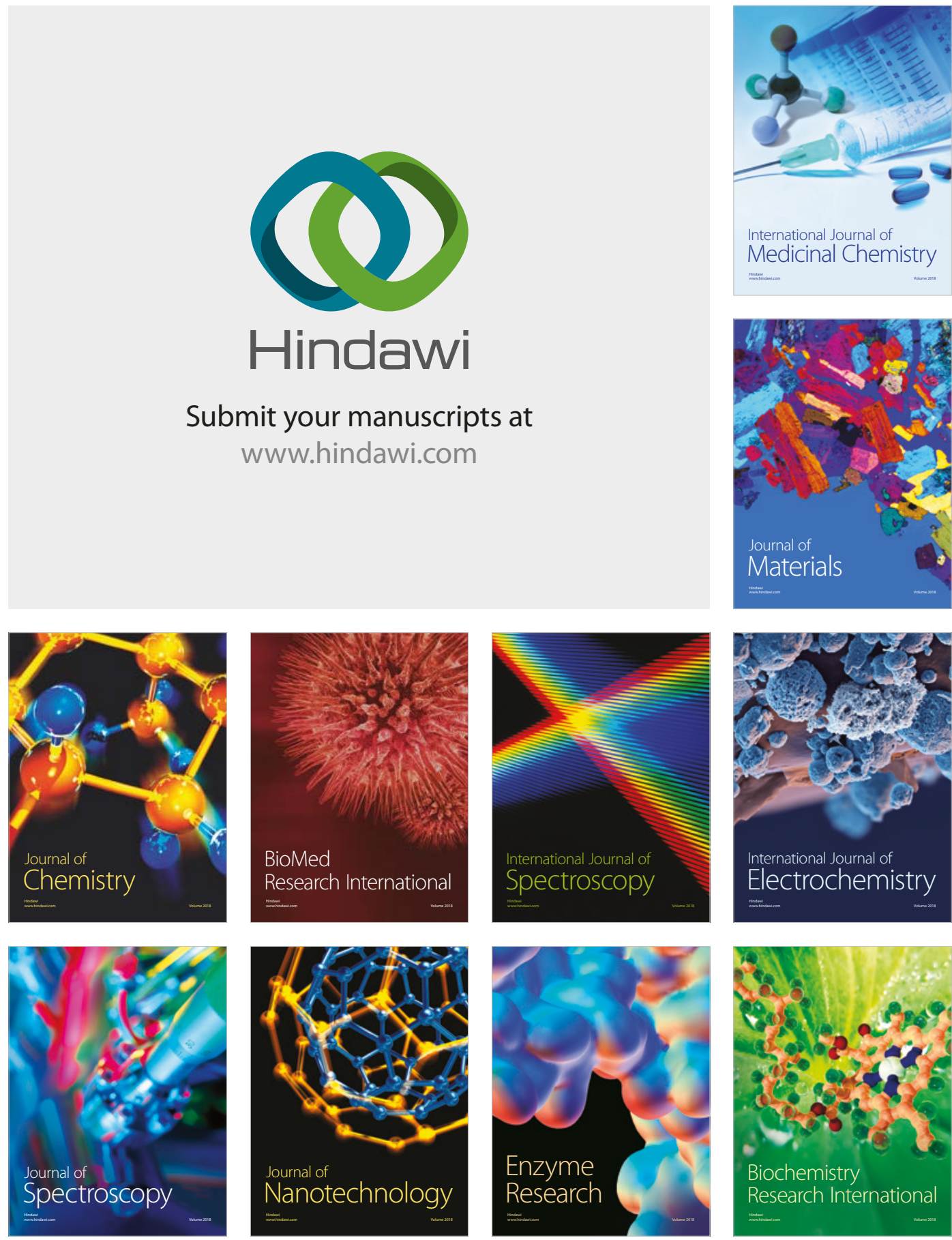
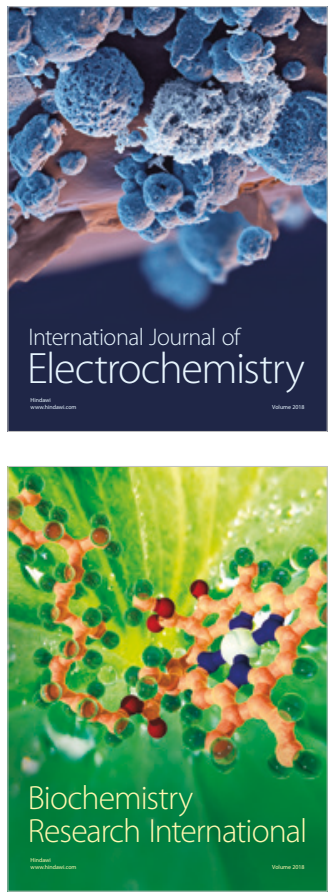